Egyptian Journal of Aquatic Biology \& Fisheries

Zoology Department, Faculty of Science,

Ain Shams University, Cairo, Egypt.

ISSN $1110-6131$

Vol. 24(4): 497 - 508 (2020)

www.ejabf.journals.ekb.eg

\title{
Reflection of Environmental Toxins on the Chemical Quality of the African Catfish
}

\author{
Ali M. Ahmed ${ }^{1}$, Mohamed A. Hussein ${ }^{2}$, Amira M. Wahdan ${ }^{1}$ and Heba M. Shaheen ${ }^{1 *}$ \\ ${ }^{1}$ Dept. of Food Hygiene, Faculty of Veterinary Medicine, Suez Canal University, Egypt \\ ${ }^{2}$ Dept. of Food Hygiene, Faculty of Veterinary Medicine, Zagazig University, Egypt \\ *Corresponding Author: hebashaheen@ymail.com
}

\section{ARTICLE INFO \\ Article History: \\ Received: June 15, 2020 \\ Accepted: July 7, 2020 \\ Online: July 11, 2020}

Keywords:

Clarias gariepinus

Chemical Quality

Heavy metals

Antibiotic

Aflatoxin

\begin{abstract}
This study was conducted on fifty fish samples of Clarias gariepinus randomly collected from Zagazig, Sharkia governorate, Egypt. The collected fish samples were evaluated for heavy metals, antibiotics and aflatoxin residues. Arsenic and Zinc residues were detected in $100 \%$ of fish samples with a mean value of $0.07 \pm 0.007$ and $5.13 \pm 0.39 \mathrm{ppm}$ respectively, while lead and mercury residues were detected in $90 \%$ of fish samples with a mean value of $0.28 \pm 0.05 \mathrm{ppm}$ and $1.4 \pm 0.24 \mathrm{ppm}$ respectively. On the other hand, cadmium residue was detected in $50 \%$ of fish samples with a mean value of $0.018 \pm 0.002 \mathrm{ppm}$. Sulfadimidin residue was detected in all examined Clarias gariepinus samples with a mean value \pm SD $(50.97 \pm 21.55$ $\mu \mathrm{g} / \mathrm{kg}$ ). All examined fish samples were below maximum residue limit 100 $\mu \mathrm{g} / \mathrm{kg}$ while aflatoxin was detected only in one fish sample with a concentration $5.32 \mu \mathrm{g} / \mathrm{kg}$ (ppb) which declared that there is no human health risk from consumption of Calais gariepinus flesh.
\end{abstract}

\section{INTRODUCTION}

Fish are currently getting expanding consideration in human food as it attracts a great percentage of the world's people for its palatability, nutritious and healthy animal protein. Fish is extensively consumed by humans in several parts of the world due to its high digestible protein content, essential amino acids, phosphorus, calcium, iron, trace elements like copper and a fair proportion of the B-vitamins to maintain good health also fish contains low amount of saturated fat, two types of omega- 3 polyunsaturated fatty acids: docosahexenoic acid (DHA) and eicosapentaenoic acid (EPA). Omega-3 (n-3) fatty acids are very essential for normal growth as they diminish cholesterol levels and the incidence of heart disease, stroke, and preterm delivery (Al bader, 2008).

Cat fish (Clarias gariepinus) belong to the family Claridae, the air-breathing catfish. They are a diverse group of ray-finned fish named for their noticable barbells that look like a cats whiskers. By increasing human activities of various kinds, such as domestic, commercial, agricultural, industrial and navigation activities, different types of waste materials enter the aquatic ecosystems led to its contamination and decrease in fish production level. (Authman, 2011). Contamination with heavy metals is a serious threat because of their toxicity, bioaccumulation, and biomagnifications in the food chain. Moreover, some aquatic organisms accumulate heavy metals to concentrations, which are higher than that present in water so they used as bio-indicators for water pollution (Mitra $\boldsymbol{e t}$ al., 2012). 
The main sources of heavy metals in the water and in the fish tissues are the surrounding atmosphere. The entrance of heavy metals to the fish tissues occur through two major pathways, directly through the digestive tract by the consumption of contaminated food or water and across permeable membranes such as gills (Ukoha et al., 2014). The human is mainly exposed for such toxic metals through ingestion of contaminated food and water, which accounted for more than $90 \%$ compared to inhalation and other exposure routes (Loutfy et al., 2006). Antibiotics are commonly used as food supplements for disease prevention and treatment and as growth promoters (Reda et al., 2013; Pham et al., 2015). However, such use of antibiotics without veterinary control leads inevitably to the presence of antibiotic residues in the animal-derived products and by-products (Mensah $\boldsymbol{e t}$ al., 2014). The utilization of antibiotic products in aquaculture is prejudicial to the aquatic environment and aqua life on one hand, and on the other hand, to the fish products consumers due to the toxicity risk of antibiotic residues (Dhaouadi et al., 2015).

This mycotoxin group mainly occurs in subtropical and tropical areas, contaminating mainly feedstuffs with high starch and lipid content, such as cottonseed, corn, peanut, wheat, and soya bean (Gonçalves et al., 2016; Ostrowski-Meissner, 1984). AFB1 is one of the most potent carcinogens known, classified as a group I carcinogen by International Agency for Research on Cancer (IARC, 1993) and highly hepatocarcinogenic (Busby and Wogan, 1984; Sharma and Salunkhe, 1991). Therefore this study was carried out to determine the residual concentration of some heavy metals ( $\mathrm{As}, \mathrm{Pb}, \mathrm{Cd}, \mathrm{Hg}$, and $\mathrm{Zn}$ ), antibiotics and aflatoxin in muscle of Clarias gariepinus and to estimate the dietary intake of determined heavy metals, as well as to assess the potential health risks associated with the consumption of Clarias gariepinus.

\section{MATERIALS AND METHODS}

\section{1-Collection of samples:}

Fifty samples of Clarias gariepinus were collected from Zagazig, Sharkia governorate, Egypt. The collected samples were kept in an icebox and directly transferred to the central Laboratory, Faculty of Veterinary Medicine, Zagazig University for heavy metal analysis. Additionally portion of samples examined for antibiotic and aflatoxin residues in animal health research institute Dokkia, Giza, Egypt

\section{2- Determination of heavy metals:}

Digestion of tissue samples were carried out according to Zantopoulos et al., (1996) then introduced for quantitative determination of heavy metals "Buck scientific $2 / 0$ VGP Atomic Absorption Spectrometer" at the faculty of Veterinary Medicine, Zagazig University.The analysis was conducted by air/ Acetylene flow $(5.5 / 1.11 / \mathrm{m})$ flame A.A.S (Buck Scientific Model 210 VGP).

\section{3- Human risk analysis of heavy metal exposure:}

Estimated daily intake (EDI) ( $\mu \mathrm{g} / \mathrm{kg} / \mathrm{day})$ for arsenic, cadmium, lead, aluminum and mercury was obtained using the following equation described by the Human Health Evaluation Manual (US Environmental Protection Agency, EPA, 2010): EDI $(\mu \mathrm{g} / \mathrm{kg} / \mathrm{day})$ was obtained using the following equation: $\mathrm{EDI}=(\mathrm{Cm} \times \mathrm{FIR}) / \mathrm{BW}$, where $\mathrm{Cm}$ is the concentration of the heavy metal in the sample ( $\mathrm{mg} / \mathrm{kg}$ wet weight); FIR is the food (fish) ingestion rate in Egypt, which was estimated at $48.57 \mathrm{~g} /$ day $(\mathbf{F A O}, \mathbf{2 0 1 0})$; BW is the body weight of Egyptian adults, which was estimated at $70 \mathrm{~kg}$ then compared to Acceptable daily intakes (ADIs). 
Target Hazard Quotient (THQ) this is the ratio between the exposure and the reference doses (RfD). Rfd represents reference oral dose that is an estimation of the daily exposure of a contaminant to which the human population may be continually exposed over a lifetime without an appreciable risk of harmful effects. (Akoto et al., 2014).

$\mathrm{RfD}$ value for $\mathrm{Cd}, \mathrm{Pb}, \mathrm{Hg}, \mathrm{As}, \mathrm{Zn}$ and $\mathrm{Cu}$ is 0.001, 0.004, 0.0003, 0.0003, 0.3and 0.04 $(\mathrm{mg} / \mathrm{kg}$ bw/day) respectively (USEPA, 2006). The population will pose no risk if the ratio is less than 1 and if the ratio is equal or greater than 1 then population will experience health risk. The following equation is used (Chien et al., 2002):

$$
T H Q=\frac{\mathrm{EF} \times \mathrm{ED} \times \mathrm{FIR} \times \mathrm{C}}{\mathrm{RFD} \times \mathrm{BW} \times \mathrm{AT}} \times 10^{-3}
$$

Where THQ is the target hazard quotient; EF is exposure frequency (365 days/year); ED is the exposure duration (70 years, average lifetime); FIR is the food ingestion rate (g/day); $\mathrm{C}$ is the heavy metal concentration in fish sample $(\mu \mathrm{g} / \mathrm{g})$; RfD is the oral reference dose $(\mathrm{mg} / \mathrm{kg} /$ day); BW is the average adult body weight $(70 \mathrm{~kg})$; and AT is the averaging exposure time ( 365 days/ year $\times$ number of exposure years, assuming 70 years).

The hazard index is the sum of the hazard quotients as described in the following equation: $\mathrm{HI}=\Sigma \mathrm{HQ}=\mathrm{HQ}$ As $+\mathrm{HQ} \mathrm{Cd}+\mathrm{HQ} \mathrm{Pb}+\mathrm{HQ} \mathrm{Al}+\mathrm{HQ}$ Hg Where $\Sigma$ HQ is the summation of hazard quotients of metals and HQ As; HQ Cd; HQ Pb; HQ Al and HQ Hg are the hazard quotients for arsenic, cadmium, lead, aluminum and mercury, respectively. It is assumed that magnitude of adverse effect will be proportional to the sum of multiple metal Exposures. When the hazard index exceeds 1.0, there is a concern for potential health hazard effect (Huang et al., 2008).

\section{Quantitative analysis of sulfadimidine residues:}

Chromatographic analysis was performed using high performance liquid chromatography system (HPLC, Agilent 1100 Series) and separation was achieved using a reversed phase C18 column $(4.6 \times 150 \mathrm{~mm}, 5 \mu \mathrm{m}$, Agilent, ZORBAX SB-C18). Sulfadimidine was extracted from fish tissue using an extraction procedure based on less organic solvent consuming methodology (Lehotay et al., 2005).

\section{Quantitative analysis of total aflatoxins residues:}

Total aflatoxins standards were obtained from Sigma (St. Louis, MO, USA) of 99\% purity. Working solution was prepared in acetonitrile and stored at $-20{ }^{\circ} \mathrm{C}$ in amber glass vials over a period of 12 months. Determination of aflatoxine residue is done by using Liquid chromatography: (HPLC) Agilent Series 1200 using fluorescence (FLD) detector with which was excitation at $360 \mathrm{~nm}$ and emission at $440 \mathrm{~nm}$. The chromatographic separation was performed with a reversed-phase column (Extend-C18, Zorbax column, 4.6 $\mathrm{mm}$ i.d., $250 \mathrm{~mm}, 5 \mu \mathrm{m}$, Agilent Co.). Extraction of aflatoxins Extraction of total aflatoxins residues from fish tissues was done according to Abd El Monem et al., (2015). SPE (Solid Phase Extraction) and derivatization step was done according to Kalantari et al., (1999), twenty $\mu 1$ were injected into HPLC (Anklam et al., 2002).

\section{Data analysis:}

Statistical analysis of data was carried out using Statistical Package for the Social Sciences (SPSS) version 16.0 (SPSS, Inc., Chicago, IL, USA, 2007). 


\section{RESULTS AND DISCUSSION}

\section{Heavy metal residues:}

The higher the contamination of heavy metals in the water body, the higher bioaccumulation of heavy metals contained in the network aquatic organisms and this represents a serious threat to humans (Tapia et al., 2012 and Shafei, 2015).

\section{I.1. Arsenic residues (As):}

The content of arsenic in fish tissues is generally due to the arsenic naturally existed in fish feeding such as macroalgae that contain high level of arsenic (Maher and Clarke, 1984). Arsenic is present in food as different species, which vary in toxicity with inorganic forms being the most toxic. Most of the arsenic in the diet is present as the less toxic organic species (Edmonds and Francesconi, 1993; Buchet et al., 1994 and Schoof et al., 1999). The data in table (1) showed that the arsenic residue detected in $100 \%$ of examined Clarias gariepinus muscle with a concentration ranged from 0.0425 to 0.1075 with a mean value of $0.07 \pm 0.007 \mathrm{ppm}$. Nearly similar level of arsenic $(0.013 \pm 0.002 \mathrm{ppm})$ was obtained in Assiut governorate by Salem (2003). Higher levels of arsenic were obtained by Rattanachongkiat et al., (2004); Mukherjee and Bhupander (2011); Budiati (2010) and El Bayomi et al., (2019) where they detected $5.8 \mathrm{ppm}$ in fish samples collected from Thailand; $0.66 \pm 0.09 \mathrm{ppm}$ from fish samples collected from India; $2.14 \pm 33,1.7 \pm 0.24$ and $1.05 \pm 0.88 \mathrm{ppm}$ in three types of fish collected from Malaysia and $0.69 \pm 0.04 \mathrm{ppm}$ in Clarias gariepinus collected from Egypt respectively. No existing legislated regulations on permissible limits for the total arsenic in seafood in Egypt but according to ISIRI No. 6952 (2014) all examined fish samples within the established limit $0.2 \mathrm{ppm}$ for fish and fish products as shown in table (1).

Table (1) Occurrence, concentration and comparison with maximum permissible limits of heavy metal residues $(\mathrm{ppm})$ in examined Clarias gariepinus muscle $(\mathrm{n}=50)$

\begin{tabular}{|c|c|c|c|c|c|}
\hline & Arsenic & Lead & Cadmium & Mercury & Zinc \\
\hline Occurrence & $100 \%$ & $90 \%$ & $50 \%$ & $90 \%$ & $100 \%$ \\
\hline Minimum & 0.0425 & 0.08 & 0.01 & 0.08 & 3.36 \\
\hline Maximum & 0.1075 & 0.48 & 0.03 & 2.2 & 7.44 \\
\hline Mean \pm SE & $0.07 \pm 0.007$ & $0.28 \pm 0.05$ & $0.018 \pm 0.002$ & $1.4 \pm 0.24$ & $5.13 \pm 0.39$ \\
\hline MPL & $0.2^{\mathrm{b}}$ & $0.1^{\mathrm{a}}$ & $0.05^{\mathrm{a}}$ & $0.2^{\mathrm{a}}$ & $40^{\mathrm{c}}$ \\
\hline Within MPL & $50(100 \%)$ & $15(30 \%)$ & $50(100 \%)$ & $5(10 \%)$ & $50(100 \%)$ \\
\hline Exceed MPL & 0 & $35(70 \%)$ & 0 & $45(90 \%)$ & 0 \\
\hline
\end{tabular}

$\mathrm{SE}=$ standard error

a according to Egyptian standard (ES 7136, 2010).

$\mathrm{b}$ according to ISIRI No. 6952

${ }^{c}$ according to Egyptian standard (ES 1-889/2005).

\section{Risk assessment of exposure to arsenic due to Clarias gariepinus consumption}

Foods having toxic substances could present a toxic threat for the consumer which is dependent on the heavy metal concentration in diet and amount of food used (Hajeb et al., 2009). Risk consists of detecting the toxicological characters related to a specific substance (Kuhnlein and Chan, 2000). The 'tolerable intake' is important to describe 'safe' levels of intake; and can be stated on a daily basis tolerable daily intake (TDI) regulated by (JECFA, 
2004). PTWI is the maximum amount of a pollutant to which individual can be exposed per week over a life span without an unacceptable risk of health problems.

\section{Estimated daily intake of arsenic (EDIAs)}

In this study, dietary exposure assessment for As through Clariasgariepinus consumption was carried out by detecting the estimated daily intake in comparison to the tolerable daily intake. The average quantity of fish consumed per adult person (assuming a $70 \mathrm{~kg}$ person) every week was 12 ounces (approximately 340 grams weekly $48.57 \mathrm{~g} /$ daily (FAO, 2010). The presented data in (table 2) revealed that estimated daily intake (EDI) of arsenic from Clariasgariepinus muscle $0.05 \mu \mathrm{g} / \mathrm{kg}$ body weight/day and not exceeded the tolerable daily intake $(2.1 \mu \mathrm{g} / \mathrm{kg}$ body weight/day) established by (JECFA, 2004). The EDI of arsenic through consumption of fish and seafood worldwide was 2.9, 0.18, 1.37 and $0.550 \mu \mathrm{g} / \mathrm{kg}$ body weight/day in Spain (Llobet et al., 2003), in India (Mukherjee and Bhupander, 2011), in Malaysia (Budiati, 2010) and in Egypt (Morshdy et al., 2015), respectively.

\section{Target hazard quotient of arsenic (THQAs)}

The THQ exceeding one indicates that there is potential risk to human safety, and THQ $\leq 1$ indicated no adverse health effects. The showed data in table (2) and declared that As THQ value was 0.167 (lower than 1). A higher THQ obtained 1.21 from consumption of fish caught in Portuguese waters (Vieira et al., 2011).

Table (2). Estimated daily intake (EDI) $\mu \mathrm{g} / \mathrm{kg}$ body weight/day in comparison to the Tolerable daily intake (TDIs) $\mu \mathrm{g} / \mathrm{kg}$ body weight, target hazard quotient (THQ) and Hazard index (HI) of different metals.

\begin{tabular}{|c|c|c|c|c|}
\hline Heavy metal & EDI & TDI $^{\text {a }}$ & THQ & Hazard index \\
\hline As & 0.05 & 2.1 & 0.167 & \multirow{2}{*}{$\mathbf{3 . 4 9}$} \\
\cline { 1 - 3 } Pb & 0.20 & 3.57 & 0.049 & \\
\hline Cd & 0.012 & 1 & 0.012 & \\
\hline Hg & 0.97 & 0.228 & 3.25 & \\
\hline Zn & 3.55 & $300-1000$ & 0.012 & \\
\hline
\end{tabular}

aJECFA Joint FAO/WHO Expert Committee on Food Additives (JECFA), 2004.

\section{II.2. Lead residues $(\mathrm{Pb})$ :}

Lead is non-essential heavy metal that have no biological role but present in all organisms. Extensive research shows that lead may have adverse health effects. Moreover, lead can mimic and construct the building blocks of DNA (nucleotides) and alter the activity of zinc in the synthesis of hemoglobin (Kirberger et al., 2013).

The data in table (1) showed that lead detected in $90 \%$ of examined samples. The lead residue level ranged from 0.08 to 0.48 with a mean value of $0.28 \pm 0.05$. The results were in line with the finding of Saei-Dehkordi and Fallah, (2011)and El Bayomi et al., (2019) who detected $0.534 \mathrm{ppm}$ of lead residue in fish samples collected from Iran and $0.42 \pm 0.04$ ppm in Clarias gariepinus collected from Egypt respectively while lower lead residue values were obtained by Jorhem and Sundström, (1993) and Suppin et al., (2005) who detected 0.008 and $0.018 \mathrm{ppm}$ of lead residue in fish samples respectively.

The data in Table (1) declared that the number of accepted samples according to lead residues was $15(30 \%)$ and the exceeded samples was $35(70 \%)$ according to the 
Regulation No. 7136/2010 of EOS, (2010), the maximum permitted limit (MPL) has been reported at $0.1 \mathrm{ppm}$ wet weight for fish. The higher percentage of fish samples exceeding the permissible limits may be due to the increased lead sources in the environment such as; lead paint, lead from combustion of fuel containing tetraethyl lead, plumbing leachates from pipes or solder and lead from leaded chips, and batteries (Committee of Environmental Health, 2005).

\section{Risk assessment of exposure to lead due to Clarias gariepinus consumption Estimated daily intake of lead (EDI Pb)}

The presented data in table (2) revealed that estimated daily intake (EDI) of lead from Clarias gariepinus sample was $0.2 \mu \mathrm{g} / \mathrm{kg}$ body weight/day. The EDI of lead from consumption of Clariasgariepinus waslower than the tolerable daily intake $(3.57-\mu \mathrm{g} / \mathrm{kg}$ body weight/day) established by JECFA (2004) which clearly, indicates that $\mathrm{Pb}$ intake for the general population from Clarias gariepinus were below the guidelines. The obtained results of the EDI of lead in this study was nearly similar to those obtained worldwide through consumption of fish where they were $0.078,0.09$ and0.372 $\mu \mathrm{g} / \mathrm{kg}$ body weight/day in Spain (Llobet et al., 2003), Portugal (Vieira et al., 2011) and Egypt (Morshdyet al., 2015), respectively.

Target hazard quotient of lead (THQ Pb)

The calculated data in table (2) declared that THQ of lead was 0.049 lower than 1. The THQ of lead was 0.021 from consumption of fish caught in Portuguese waters (Vieira et al., 2011), $0.11,0.06$ and 0.12 from consumption of Brush tooth Lizard fish, Mackerel and Horse Mackerel (Ali, 2018) and 0.06 from consumption of Clarias gariepinus in Egypt (El Bayomi et al., 2019)

\section{I.3. Cadmium residues $(\mathrm{Cd})$}

Cadmium accumulates in human's body from food chain magnification and has the ability to induce kidney dysfunction, skeletal damage, and also affect reproductive system (WHO, 2003). The results in table (1) showed that cadmium residue detected in $50 \%$ of examined samples where its concentration was ranged from 0.01 to $0.03 \mathrm{ppm}$ with a mean value of $0.018 \pm 0.002 \mathrm{ppm}$ as shown in table (2).A higher Cd level was obtained by El Bayomi et al., (2019) they detected $(0.19 \pm 0.02 \mathrm{ppm})$ in Clarias gariepinus collected from Egypt. Considering the existing legislated regulations on permissible limits of cadmium (ES: 7136/2010), the maximum permitted limit (MPL) has been reported at $0.05 \mathrm{ppm}$ wet weight for fish which mean that all examined samples of Clarias gariepinus were accepted.

\section{Risk assessment of exposure to cadmium due to Clariasgariepinus consumption} Estimated daily intake of cadmium (EDI Cd)

The presented data in table(2) revealed that estimated daily intake (EDI) of cadmium was $0.012 \mu \mathrm{g} / \mathrm{kg}$ body weight/day which is lower than the tolerable daily intake $(1 \mu \mathrm{g} / \mathrm{kg}$ body weight/day) established by JECFA (2004). That's clearly indicates that Cd intake for the general population from Clarias gariepinus samples is below the guidelines. The EDI of cadmium through consumption of fish and seafood worldwide was $0.055,0.13$ and $0.007 \mu \mathrm{g} / \mathrm{kg}$ body weight/day in Spain (Llobetet al., 2003), India (Mukherjee and Bhupander, 2011) and Egypt (Morshdy et al., 2015), respectively.

\section{Target hazard quotient of cadmium (THQ Cd)}

The THQ exceeding 1 indicates that there is potential risk to human health, and THQ $\leq 1$ indicated no adverse health effects. The showed data in table (2) declared that THQ of cadmium 0.012 lower than one. The THQ of cadmium was 0.002 to 0.19 from consumption of fish caught in Portuguese waters (Vieira et al., 2011).And 0.02, 0.024 and 
0.03 from consumption of Brush tooth Lizard fish, Mackerel and Horse Mackerel in Egypt (Ali, 2018).

\section{I.3. Mercury residues $(\mathrm{Hg})$ :}

Mercury compounds are highly toxic, because they are fat-soluble, easily absorbed, and accumulated in erythrocytes and CNS (Castoldi et al., 2003). The results in table (1) showed that the mercury residue detected in $90 \%$ of examined Clarias gariepinus samples where its level ranged from 0.08 to $2.2 \mathrm{ppm}$ with a mean value of $1.4 \pm 0.24 \mathrm{ppm}$. Nearly similar value for mercury level was obtained by El Bayomi et al., (2019) detected (1.02 \pm $0.08 \mathrm{ppm}$ ) of mercury residue in Clarias gariepinus collected from Egypt while lower values was obtained by Mukherjee and Bhupander (2011) who detected $0.62 \pm 0.05 \mathrm{ppm}$ of mercury residue in fish samples collected from India and Morshdy et al., (2007) who reported $0.54 \pm 0.03$ and $0.56 \pm 0.01 \mathrm{ppm}$ in Brush tooth Lizard fish and Mackerel fish samples collected from Egypt respectively.

According to ES (7136/2010) the maximum permitted limit (MPL) is $0.2 \mathrm{ppm}$ wet weight for fish. The results in table (1) declared that the numbers of accepted samples according to mercury residue were 5(10\%) and the exceeded samples resemble $45(90 \%)$ according to EOS (2010) permissible limits.

\section{Risk assessment of exposure to mercury due to Clarias gariepinus consumption Estimated daily intake of mercury (EDI Hg)}

The presented data in table (2) revealed that estimated daily intake (EDI) of mercury was $0.97 \mu \mathrm{g} / \mathrm{kg}$ body weight/day which is higher than the tolerable daily intake $(0.228-\mu \mathrm{g} /$ $\mathrm{kg}$ body weight/day) established by JECFA (2004). That's clearly, indicates the Hg intake for the general population from Clarias gariepinus samples may lead to public health hazard and mercury toxicity. The EDI of mercury through consumption of fish and seafood worldwide was $0.14,(0.17$ in summer and 0.086 in winter $), 0.17,0.021$ and $0.56 \mu \mathrm{g} / \mathrm{kg}$ body weight/day in Spain (Llobet et al., 2003), Iran (Maghtouie et al., 2011), India (Mukherjee and Bhupander, 2011), Egypt (Morshdy et al., 2015) and (El Bayomi et al., 2019), respectively.

\section{Target hazard quotient of mercury (THQ Hg)}

The calculated data in table (2) declared that THQ of mercury 3.25 was more than one while lower results were obtained by Vieira et al., (2011), Ali (2018) and El Bayomi et al., (2019) who reported that THQ of mercury was ranged from 0.025 to 1.30 from consumption of fish caught in Portuguese waters, 0.025, 0.19and 0.15 from consumption of Brush tooth Lizard fish, Mackerel and Horse Mackerel in Egypt and 0.35 from consumption of Clarias gariepinus collected from Egypt respectively.

\section{I.4. Zinc residues $(\mathrm{Zn})$ :}

Zinc is an essential nutrient for almost all plants. For this reason, algae growing in streams and lakes can absorb a large part of the zinc dissolved in water. In addition to its nutritive effect, zinc is also toxic to most forms of plants when present in amounts exceeding certain limits (Krishna et al., 2014). The data in table (1) showed that Zn was detected in $100 \%$ of examined Clarias gariepinus muscle. The tissue concentrations of zinc ranged from 3.36 to $7.44 \mathrm{ppm}$ with mean values of $5.13 \pm 0.39 \mathrm{ppm}$. Nearly similar values was obtained by El-Sayed et al., (2011) who detected (3.84 to $5.67 \mathrm{ppm}$ ) of Zinc concentrations in Clarias gariepinus while higher zinc content has been reported in the range 55.8-60 mg/kg in fish species from Lake Qarun by Mohamed and Gad (2008), 13$39 \mathrm{mg} / \mathrm{kg}$ in fish species from Rosetta Branch of River Nile by Gad and Yacoub (2009) and $0.1-70 \mathrm{mg} / \mathrm{kg}$ in fish species from Nile delta Egypt by Zyadah (2005). The data in 
table (1) declared that all examined Clarias gariepinus samples were located within the established limit $40 \mathrm{ppm}$ for fish according to Egyptian slandered (EOS, 2010).

\section{Risk assessment of exposure to zinc due to fish consumption Estimated daily intake of zinc (EDI Zn)}

The presented data in table (2) revealed that the estimated daily intake (EDI) of zinc from Clarias gariepinus samples was $3.68 \mu \mathrm{g} / \mathrm{kg}$ body weight/day and not exceeded the tolerable daily intake $(300 \mu \mathrm{g} / \mathrm{kg}$ body weight/day) established by JECFA (2004). Higher value of EDI $(5.37 \mu \mathrm{g} / \mathrm{kg}$ body weight/day) of zinc through consumption of fish in India was obtained by Krishna et al. (2014) while lower results $(1.703 \mu \mathrm{g} / \mathrm{kg}$ body weight/day) was obtaiened by Morshdy et al. (2015) through consumption of fish in Egypt.

\section{Target hazard quotient of zinc (THQ Zn)}

The data shown in table (2) declared that $\mathrm{Zn}$ THQ value was 0.012 which is lower than one. On the other hand higher value of Zn THQ (17.9) was obtained by Krishna et al., (2014) from consumption of fish caught from Machilipatnam coast, Andhra Pradesh, India. Hazard index (HI) defined as $\Sigma$ THQ can be estimate the risk of mix pollutants (USEPA, 1989). HI value of Clarias gariepinus was higher than 1 (3.49) as shown in table (2) for adult, indicating that there is health risk for the consumer by ingesting multiple metals contained in Clarias gariepinus.

\section{Antibiotic residues in Clariasgariepinus:}

One of the most important concerns to consumer is the consumption of food containing chemical additives particularly animal drug residues, which produce adverse effects in humans (Donoghue, 2003).

The sulfonamide group includes a large number of compounds which have been used for a very long time, including sulfadiazine, sulfamethizole, sulfamethoxazole, sulfasalazine, sulfisoxazole, and various high-strength combinations of three sulfonamides. At present, sulfonamides and other drugs (chlortetracycline, penicillin, and several ionophores) are the most common contaminating antimicrobials in animal feed, generating potentially serious problems in human health (Wang et al., 2006).

Table (3) Occurrence of sulfadimidine and aflatoxin residues in examined Clarias gariepinus muscle $(\mathrm{n}=5)$

\begin{tabular}{|c|c|c|}
\hline Sample & Sulfadimidine $(\boldsymbol{\mu g} / \mathbf{k g})$ & Aflatoxin $(\boldsymbol{\mu g} / \mathbf{k g})$ \\
\hline 1 & 50.83 & ND \\
\hline 2 & 87.5 & ND \\
\hline 3 & 37.5 & ND \\
\hline 4 & 33.2 & 5.32 \\
\hline 5 & 45.83 & ND \\
\hline Mean \pm SD & $50.97 \pm 21.55$ & - \\
\hline
\end{tabular}

$\mathrm{SD}=$ Standard deviation

$\mathrm{ND}=$ Not detected

The EU has set Maximum residue limit (MRL) for total sulfonamide concentration in fish at $100-\mu \mathrm{g} \mathrm{kg}-1$. The data in table (3) declared that sulfadimidin residue was detected in all examined Clarias gariepinus samples with minimum 33.2, maximum 87.5, and mean value $\pm \mathrm{SD}(50.97 \pm 21.55 \mu \mathrm{g} / \mathrm{kg}$ ). All examined samples were below Maximum residue limit $100 \mu \mathrm{g} / \mathrm{kg}$. Sulfonamide previously detected within different concentration in sea bass 
$271 \mu \mathrm{g} / \mathrm{kg}$, and in rainbow trout sample with at concentration of $56 \mu \mathrm{g} / \mathrm{kg}$ (Yipel $\boldsymbol{e t}$ al., 2017).

\section{Aflatoxin residues in Clarias gariepinus:}

The aflatoxine occurrence in those fish samples could be attributed to the presence of mycotoxin in fresh fish tissues once the contaminated feed is ingested by farmed fish (Sun et al., 2015). The results in table (3) declared that aflatoxin was detected only in one sample from five samples with a concentration $5.32 \mu \mathrm{g} / \mathrm{kg}(\mathrm{ppb})$ where nearly similar results was obtained by Sun et al., (2015) who detected aflatoxin only in one sample from examined carp purchased from local supermarkets in Shanghai city, China with a concentration of 1.2 $\mu \mathrm{g} / \mathrm{kg}$. Meanwhile, aflatoxin was not detected in raw fish samples from Spain (Carballo et al., 2018), Smoked fish and sushi from Japan (Tolosa et al., 2019).

There is no Egyptian regulation for aflatoxin in fish flesh but because of the potential health hazards of mycotoxin for humans, threshold levels of aflatoxin in commodities have been established worldwide. A maximum residue limit of $20 \mu \mathrm{g} / \mathrm{kg}$ (FDA, 2000) and $4 \mu \mathrm{g} / \mathrm{kg}$ (FAO, 2004) for total aflatoxin in foods. Comparing the obtained results declared that there is no possibility aflatoxin exposure and human health risk from consumption of Calais gariepinus flesh.

\section{CONCLUSION}

The obtained results declared that Clarias gariepinus flesh was contaminated with various concentrations of heavy metals where the level of arsenic, cadmium, and zinc was within the permissible limit while the level of lead and mercury exceeded the permissible limit in most of examined samples. The estimated daily intake of arsenic, lead, cadmium and zinc below the tolerable daily intake. Meanwhile, mercury exceed the tolerable daily intake so, possible risk may occur in population consumed Clariasgariepinus flesh. Antibiotic residue (sulfadimidin) detected in all examined Clariasgariepinus flesh samples but within the permissible limit while Aflatoxin residue was detected only in one sample of Clariasgariepinus flesh and located below the permissible limit.

\section{REFERENCES}

Abd El Monem, M.; Ragab, M.; Maher, M.A.; Ali, S.H.H.; Salah, N.; Hussein, H.M.A and Amr, F.H. (2015): Detection of aflatoxins in meat by modified HPLC method. Egypt. J. Chem. Environ. Health. 1, 945-954.

Akoto, O.; Bismark Eshun, F.; Darko, G. and Adei, E. (2014): Concentrations and health risk assessments of heavy metals in fish from the Fosu Lagoon. International Journal of Environmental Research. 8(2): 403-410.

Al bader, N. (2008): heavy metal levels in most common available fish species in Saudi market. J. of food technology. 6 (4): p. 173- 177.

Ali, E.T. (2018): Chemical safety of imported frozen fish. M.V.Sci. Thesis. (Meat Hygiene). Fac. Vet. Med. Zag. Univ. Egypt.

Anklam, E.; Stroka, J. and Boenke, A. (2002): Implementation of EU legislation with afocus on mycotoxins. Food Control, 13: 173- 183, 16th ed. Association of Analytical Communities (AOAC) (1995): Method 990.33, Official methods of analysis.

Authman, M. M. (2011): Environmental and experimental studies of aluminium toxicity on the liver of Oreochromis niloticus (Linnaeus, 1758) fish. Life Science Journal, 8(4): 764-776.

Buchet, J. P.; Pauwels, J. and Lauwerys, R. (1994): Assessment of exposure to inorganic arsenic following ingestion of marine organisms by volunteers. Environ Research. 66:44-51.

Budiati, T. (2010): The presence of arsenic as heavy metal contaminant on salmon: a risk assessment. International Journal of Basic and Applied Sciences.10(5): 6-12. 
Busby, W. F. and Wogan, G. N. (1984): Aflatoxins. In: Searle CEE (ed) Chemical carcinogenesis. American Chemical Society, Washington, DC: 945-1136.

Carballo, D.; Font, G.; Ferrer, E. and Berrada, H. (2018): Evaluation of mycotoxin residues on ready-to-eat food by chromatographic methods coupled to mass spectrometry in tandem Toxins, 10(6): 243.

Castoldi, A. F.; Coccini, T. and Manzo, L. (2003): Neurotoxic and molecular effects of methyl mercury in humans. Reviews on Environmental Health. 18:19- 31.

Chien, L. C.; Hung, T. C.; Choang, K. Y.; Yeh, C. Y.; Meng, P. J.; Shieh, M. J. and Han, B. C. (2002): Daily intake of TBT, Cu, Zn, Cd and As for fishermen in Taiwan. Science of the total environment. 285(1-3): 177-185.

Committee on Environmental Health. (2005): Lead exposure in children: prevention, detection, and management. Pediatrics. 116(4): 1036-1046.

Dhaouadi, R.; Tarhouni, D.E. and Louati, A. (2015): Utilisation des antibiotiques en aquaculture. http://docplayer.fr/22592327-Utilisation-des antibiotiques en aquaculture. Html. Accessed 10.3. 2018.

Donoghue, D. (2003): Antibiotic residues in poultry tissues and eggs, human health concerns. Poultry Science. 82: 618-621.

Edmonds, J.S. and Francesconi, K.A. (1993): Arsenic in seafood's: human health aspects and regulations. Marine Pollution. 26:665-674.

Egyptian Organization for Standardization and Quality control (EOS.NO.7136) (2010): Maximum level for certain contaminants in food stuffs. ES NO.7136/2010. Cairo, Egypt.

El Bayomi, R. M.; Darwish, W. S. and Elawady, E. F. (2019): Risk Assessment of some Heavy Metals from Claris gariepinus (African catfish) Consumed in Sharkia Governorate, Egypt. Zagazig Veterinary Journal, 47(2): 193-202.

El-Sayed, E. A.; El-Ayyat, M. S.; Nasr, E. and Khater, Z. Z. K. (2011): Assessment of heavy metals in water, sediment and fish tissues, from Sharkia province, Egypt. Egypt. J. Aquat. Biol. \& Fish, 15(2): 125-144.

FDA (2000): Guidance for industry: Action levels for poisonous or deleterious substances in human food and animal feed <http://www.fda.gov/Food/GuidanceComplianceRegulatoryInformation/GuidanceDocumen ts/ChemicalContaminantsandPesticides/ucm077969.htm\#afla > Last updated 11.09.11

FAO "Food and Agriculture Organization" (2004): Worldwide regulations for mycotoxins in food and feed in 2003. Food and Nutrition Paper, FAO, Rome. Paper 81.

FAO (Food Agriculture Organization) (2010): Nutrition Country Profiles - Egypt. FAO, Rome, Italy.

Gad, N.S. and Yacoub A. M. (2009): Antioxidant defense agents and physiological responses of fish to pollution of Rosetta Branch of River Nil Egypt, Egyptian Journal of Aquatic Biology and Fisheries 13(4): 109-128.

Gonçalves, R.A.; Naehrer, K. and Santos, G.A. (2016): Occurrence of mycotoxins in commercial aquafeeds in Asia and Europe: a real risk to aquaculture? Reviews in aquaculture, n/a-n/a.

Hajeb, P.; Jinap, S.; Ismail, A.; Fatimah, A. B.; Jamilah, B. and Rahim, M. A. (2009): Assessment of mercury level in commonly consumed marine fishes in Malaysia. Food Control. 20(1): 79-84.

Huang, M.; Zhou, S.; Sun, B. and Zhao, Q. (2008): Heavy metals in wheat grain: assessment of potential health risk for inhabitants in Kunshan, China. Science of the Total Environment. 405(1-3): 54-61.

International Agency for Research on Cancer (IARC) (1993): Some naturally occurring substances: food items and constituents, heterocyclic aromatic amine and mycotoxins, In Working Group on the Evaluation of Carcinogenic Risks to Humans. IARC, Lyon.

ISIRI No. 6952 (2014): Institute of Standards and Industrial Research of Iran. Fish and fish products. http://www.anytest.co.kr/isiri-7/?ckattempt $=1$.

JECFA Joint FAO/WHO Expert Committee on Food Additives (JECFA), (2004): Safety evaluation of certain food additives and contaminants. WHO Food Additives Series No. 52. World Health Organization, Geneva

Jorhem, L. and Sundström, B. (1993): Levels of lead, cadmium, zinc, copper, nickel, chromium, manganese, and cobalt in foods on the Swedish market, 1983-1990. Journal of Food Composition and Analysis. 6(3): 223-241. 
Kalantari, H.; Zandmoqadam, H. and Abdolahilorestani, S. (1999): Determination of aflatoxins B1 and M1 in liver by HPLC. Journal of Ahwaz University Agriculture, 22 (1): 10.

Kirberger, M.; Wong, H. C.; Jiang, J. and Yang, J. J. (2013): Metal toxicity and opportunistic binding of $\mathrm{Pb} 2+$ in proteins. Journal of inorganic biochemistry. 125: 40-49.

Krishna, P. V.; Jyothirmayi, V. and Rao, K. M. (2014): Human health risk assessment of heavy metal accumulation through fish consumption, from Machilipatnam Coast, Andhra Pradesh, India. Journal Issues ISSN, 2360, 8803.

Kuhnlein, H. V. and Chan, H. M. (2000): Environment and contaminants in traditional food systems of northern indigenous peoples. Annual Review of Nutrition. 20(1): 595-626.

Lehotay, S. J.; Mastovska, K. and Yun, S. J. (2005): Evaluation of two fast and easy methods for pesticide residue analysis in fatty food matrixes. J. AOAC Int. 88: 630-638.

Llobet, J. M.; Falco, G.; Casas, C.; Teixido, A. and Domingo, J. L. (2003): Concentrations of arsenic, cadmium, mercury, and lead in common foods and estimated daily intake by children, adolescents, adults, and seniors of Catalonia, Spain. Journal of Agricultural and Food Chemistry. 51(3): 838-842.

Loutfy, N.; Fuerhacker, M.; Tundo, P.; Raccanelli, S.; El Dien AG and Ahmed MT (2006): Dietary intake of dioxins and dioxin-like PCBs, due to the consumption of dairy products, fish/seafood and meat from Ismailia city, Egypt. Sci Total Environ 370:1-8.

Maghtouie, A. H.; Neissi, G.; Nasseri, S.; Gholaminezhad, E.; Shalamzari, N. and Nikpour, Y. (2011): Determination of mercury in mullet fish (Liza abu) from Arvand River, Iran. World Journal of Fish and Marine Sciences. 3(6): 514-517.

Maher, W. A. and Clarke, S. M. (1984): The occurrence of arsenic in selected marine macroalgae from two coastal areas of South Australia. Marine Pollution Bulletin. 15(3): 111-112.

Mensah, S.E.P.; Koudandé, O.D.; Sanders, P.; Laurentie, M.; Mensah, G.A. and Abiola, F.A. (2014): Résidus d'antibiotiques et denrées d'origine animale en Afrique: risques de santé publique, Rev. Sci. Tech. Off. Int. Epiz. 33 (3): 1-27.

Mitra, A.; Barua, P.; Zaman, S. and Banerjee, K. (2012): Analysis of trace metals in commercially important crustaceans collected from UNESCO protected world heritage site of Indian Sundarbans. Turkish Journal of Fisheries and Aquatic Sciences, 12(1): 53-66.

Mohamed, F.A.S. and Gad, N.S.: (2009): Bioaccumulation, some blood biochemical changes and histological alteration in selected tissues of Oreochromis niloticus exposed to Zinc and/ or Cadmium. American Eurasian Journal of Agricultural and Environment Science, 5 (3): 441455.

Morshdy, A.; Darwaish, S.; Hussein, M. and El Ebidy O. (2015): Heavy Metal Residues in Marketed Fish at Manzalla Dakahllyia. $2^{\text {nd }}$ Conference of Food Safety, Suez Canal University, Faculty of Veterinary Medicine. Volume I August: 111-118.

Morshdy, A.; Eldosky, K.E. and El-Sebaie, S. (2007): Some heavy metal residues in mackerel and saurus fish. Zag. Vet. J. 35(4):114-120.

Mukherjee, D. P. and Bhupander, K. (2011): Assessment of Arsenic, Cadmium, and Mercury Level In Commonly Consumed Coastal Fishes from Bay of Bengal, India. Food Science and Quality Management. www. iiste. org. Diakses. 16.

Ostrowski-Meissner, H.T. (1984): Effect of contamination of foods by Aspergillus flavus on the nutritive value of protein. J Sci Food Agric 35:47-58.

Pham, D.K.; Chu, J.; Do, N.T.; Brose, F.; Degand, G.; Dela- haut, P.; De Pauw, E.; Douny, C.; Van Nguyen, K.; Dinh Vu, T.; Scippo, M.-L. and Wertheim, H.F.L. (2015): Monitoring antibiotic use and residue in freshwater aquaculture for domestic use in Vietnam. Eco Health, 12 (3): 480-489.

Rattanachongkiat, S.; Millward, G. E. and Foulkes, M. E. (2004): Determination of arsenic species in fish, crustacean and sediment samples from Thailand using high performance liquid chromatography (HPLC) coupled with inductively coupled plasma mass spectrometry (ICP-MS). Journal of Environmental Monitoring. 6 (4): 254-261.

Reda, R. M.; Ibrahim, R. E.; Ahmed, E. N. G. and El-Bouhy, Z. M. (2013): Effect of oxytetracycline and florfenicol as growth promoters on the health status of cultured Oreochromis niloticus Egypt. J. Aquat. Res., 39(4): 241-248.

Saei-Dehkordi, S. S. and Fallah, A. A. (2011): Determination of copper, lead, cadmium and zinc content in commercially valuable fish species from the Persian Gulf using derivative potentiometric stripping analysis. Microchemical Journal. 98(1): 156-162. 
Salem, D.A. (2003): Survey of some environmental pollutants in freshwater fishes in Assiut governorate, Egypt. Ass. Univ. Bull. Environ. Res. 6 ( 2): 15-38.

Schoof, R.A.; Yost, L. J.; Eickhoff, E. A.; Crecelius, E.A.; Cragin, D, W.; Meacher, D. M. and Menzel, D. B. (1999): A market basket survey of inorganic arsenic food. Food and Chemical Toxicology. 37:839-846.

Shafei, H. M. E. L. (2015): Some heavy metals concentration in water, muscles and gills of Tilapia Niloticus as biological indicator of Manzala Lake Pollution. J. of Aquaculture Research and Development. 6: 358.

Sharma, R.P. and Salunkhe, D.K. (1991): Mycotoxins and phytotoxins, Press, C., ed. (Boca Raton, FL).

SPSS, 16 (2007): Statistical Package for Social Science ver. 16 for Windows. SPSS (Inc., Chicago, IL.).

Sun, W.; Han, Z.; Aerts, J.; Nie, D.; Jin, M.; Shi, W., \& Wu, A. (2015): A reliable liquid chromatography-tandem mass spectrometry method for simultaneous determination of multiple mycotoxins in fresh fish and dried seafoods. Journal of Chromatography A, 1387: 42-48.

Suppin, D.; Zahlbruckner, R.; Krapfenbauer-Cermak, C. H.; Hassan-Hauser, C. H. and Smulders, F. J. M. (2005): Mercury, lead and cadmium content of fresh and canned fish collected from Austrian retail operations. Arbeitstagung Des Arbeitsgebietes Lebensmittelhygiene. 46: 633.

Tapia, J.; Chacoff, L. V.; Bertrán, C.; Cortés, F. P.; Hauenstein, E.; Schlatter, R.; Jiménez, C. and Tapia, C. (2012): Heavy metals in the liver and muscle of Micropogonias manni fish from Budi Lake, Araucania Region, Chile: potential risk for humans. Environ. Monitoring and Assessment. 184:3141-3151.

Tolosa, J.; Barba, F. J.; Font, G.and Ferrer, E. (2019): Mycotoxin Incidence in Some Fish Products: QuEChERS Methodology and Liquid Chromatography Linear Ion Trap Tandem Mass Spectrometry Approach. Molecules, 24(3): 527.

Ukoha, P. O.; Ekere, N. R.; Udeogu, U. V. \& Agbazue, V. E. (2014): Potential health risk assessment of heavy metals [ $\mathrm{Cd}, \mathrm{Cu}$ and $\mathrm{Fe}$ ] concentrations in some imported frozen fish species consumed in Nigeria. Int. J. Chem. Sci, 12(2): 366-374.

US Environmental Protection Agency, EPA (2010): Integrated Risk Information System (IRIS). Cadmium (CASRN-7440-43-9) http://www.epa.gov/ iris/subst/0141.htm (Accessed 18.04.2013).

USEPA (2006): United States, Environmental Protection Agency, Integrated Risk Information System, [http://www. epa. gov/ iris/substS].

USEPA, (United States Environment Protection Agency) (1989): Risk Assessment Guidance for Superfund, Vol 1. EPA/540/1-89/002. Office of Emergency and Remedial Response, USEPA, Washington, DC.

Vieira, C.; Morais, S.; Ramos, S.; Delerue-Matos, C. and Oliveira, M. B. P. P. (2011): Mercury, cadmium, lead and arsenic levels in three pelagic fish species from the Atlantic Ocean: intra-and inter-specific variability and human health risks for consumption. Food and Chemical Toxicology, 49(4): 923-932.

Wang, S.; Zhang, H.; Wang, L.; Duan, Z. J. and Kennedy, I. (2006): Food Add Contam 23: $362-384$.

WHO (2003): Cadmium in drinking-water. Background document for preparation of WHO Guidelines for drinking-water quality Geneva, World Health Organization (WHO/ SDE/ WSH/ 03 04/80.

Yipel, M.; Kürekci, C.; Tekeli, İ. O.; Metli, M. and Sakin, F. (2017): Determination of selected antibiotics in farmed fish species using LC- MS/MS. Aquaculture research. 48(7): 38293836.

Zantopoulos, N.; Antoniou, V.; Petsaga, V. and Zdragas, A. (1996): Copper concentrations in sheep liver and kidney in Greece. Veterinary and human toxicology. 38(3): 184-185.

Zyadah, M.A.: (2005): Monitoring of heavy metals in water and fish at northern region of Nile Delta Egypt. Journal of the Egyptian German Society of Zoology 46 (D): 141-157. 